\title{
Interleukin-6 Receptor Subunit Beta
}

National Cancer Institute

\section{Source}

National Cancer Institute. Interleukin-6 Receptor Subunit Beta. NCI Thesaurus. Code C26265.

Interleukin-6 receptor subunit beta (918 aa, 104 kDa) is encoded by the human IL6ST gene. This protein is involved in cytokine receptor-mediated signal transduction. 